the significance of the difference is not explained.

Recent events in the region have no doubt had a profound effect on some species, yet to be documented. Other species continue to be discovered in the region: the African bushy-tailed mongoose Bdeogale crassicauda was recorded for the first time in Arabia in 1988 and published too late for inclusion. This volume is a timely reminder of the fragility of these arid habitats and the precarious status of many of their endemic mammals at a time when rain forests, at the opposite end of the habitat spectrum, are uppermost in the public mind.

Gordon B. Corbet.

\section{Elephant Life}

Irven O. Buss

Iowa State University Press, Ames, Iowa, 1990, 191 pp., HB $\$ 49.95$

Professor Irven Buss, a leading American wildlife zoologist, has devoted much of his career to study of the African elephant, largely in Kibale Forest Reserve of western Uganda and adjacent areas. This book, subtitled 'Fifteen Years of High Population Density', sets out his research findings.

It makes fascinating reading, dealing in detail with many aspects of elephant life, as manifested by the many individuals that Buss tracked over extended periods of time. Chapters deal with all aspects of behaviour, numbers and distribution, herd movements, reproductive patterns, food habits, life in forest habitats, indeed whatever makes elephants tick especially when they become unduly crowded in protected areas. A concluding chapter considers the survival outlook for the Kibale elephants-not promising in the light of landhunger pressures on the part of human communities in the environs.

Along the way Buss covers such topics as threat displays and fighting, ear flapping, 'rumblings', migration, and minerals in the diet. There are many illuminating accounts of elephants' responses when a member of the herd dies; methods of pushing over trees; tusk gouging and bark stripping and care of the young. Also there are detailed reports of phenomena that I have not previously come across in any detail, let alone such splendidly graphic detail, such as killing crocodiles. It all makes for a splendid compendium of sustained observations of elephants' lifestyles, with stacks of data-supported records. A fine publication that will appeal to both the professional zoologist and the elephant enthusiast. Norman Myers.

\section{Dolphins, Porpoises and Whales of the World. The IUCN Red Data Book} Margaret Klinowska (Compiler) IUCN, Cambridge, 1991, ISBN 2880329361,438 pp., $\mathrm{HB} £ 30 / \$ U S 55$ postage and packing extra

This new book in the IUCN Red Data Book series reviews the status of the world's 79 species of cetaceans. While none has yet become extinct through man's activities some of the great whales and river dolphins have total populations of only a few hundred and many species of large or unknown size are probably declining rapidly. Detailed species accounts describe distribution, population size, threats and conservation measures necessary.

Editor.

\section{Extraordinary Animals Worldwide}

Karl P. N. Shuker

Robert Hale, London, 1991, 208 pp., £15.95

This is one of those irritating titles that leaves you to guess what the book is actually about. The subject-matter is in fact zoological mysteries of the kind that have been dealt with more thoroughly by Bernard Heuvelmans in On the Track of Unknown Animals (1958). Inevitably, the author covers some of the same ground, as with the alleged South American ape Ameranthropoides loysi from the borders of Colombia and Venezuela, recorded once only, in 1929. He wisely avoids the well-trodden paths to the lake monsters and the bigfoot clan, but strays rather far in the direction of pure folklore and travellers' tales, for instance with the story of the so-called daisy dog, a pekinese alleged to have been shipwrecked in Cornwall in the 16 th century. If you like reading about this sort of thing, then here is a good read.

To return to the South American ape, I was struck by the chapter of accidents that always occurs when a potential zoological specimen actually appears, as has so often been related by the bigfoot fans. The ape, a female, was shot by a party of geologists, but the specimen was reduced to a skin and a skull. The skull was used as a salt-container by the party's cook, so that it completely disintegrated, and the skin suffered 'a comparably regrettable fate', leaving only a striking photograph as evidence. All that zoologists ever ask in these cases is a physical specimen of some kind. In one way or another they are always denied it.

Richard Fitter. 